\title{
Aberrant Expression of the p53 Tumor Suppressor Gene in Pediatric Acute Lymphoblastic Leukemia
}

Amine Moueden ${ }^{1 *}$, Driss Benlaldj ${ }^{1}$, Amaria Boumeddane ${ }^{2}$ and Fatima Seghier ${ }^{1}$

${ }^{1}$ Department of Hemobiology, University Hospital, Oran, Algeria

${ }^{2}$ Center Anti-Cancer, Emir Abdel Kader, Oran, Algeria

\begin{abstract}
The TP53 tumor suppressor gene is the gene most studied by oncology researchers; the alteration of this gene is the most common genetic alteration in human cancers (more than $50 \%$ ); our study consisted of determining the mutational status of TP53 in LAL patients. This is a prospective study from September 2014 to March 2017 , based on a diagnostic strategy whose ICC immunocytochemical technique was chosen as a functional screening technique for TP53 alterations, then detection of TP53 mutations was made by the sequencing and the detection of deletions by the FISH. The frequency of TP53 abnormalities detected by immunocytochemical technique is $12.2 \%$ (all are indirect alterations of the P53 gene). Our study showed a significant correlation between P53 abnormalities and the time of research of TP53 abnormality and also with the early response to prednisone at $d 08(p=0.011, p=0.043$ respectively). In univariate analysis, progression-free survival and overall survival studies showed shorter survival in the presence of the TP53 abnormality $(p=0.001)(p=0.033)$ respectively. In multivariate analysis, we found that TP53 abnormality is the only independent predictor of progression-free survival (hazard ratio [HR] $=7,540 p=0.047$ ), but it is not in overall survival.
\end{abstract}

Keywords: P53; Immunocytochimestry; LAL; Abnormalities; Gene

\section{Introduction}

The P53 tumor suppressor gene is par excellence the gene most studied by researchers specialized in oncology. The alteration of the P53 gene is the most common genetic alteration in human cancers (more than 50\%) [1-8]

Several studies have shown that the abnormality of P53 in lymphoid hemopathies and more particularly in acute lymphoblastic leukemia [911]. It is associated with a poor prognosis and resistance to dependent P53 treatments $[12,13]$.Although bone marrow transplantation is the treatment of choice in patients with P53 abnormality, its success and the availability of a compatible donor remains a major obstacle to its realization. A group of new substances with a mechanism of action bypassing the onco-suppressive protein-dependent pathway, such as those targeting the B cell receptor (BCR) pathway, are currently in use or are in a trial phase clinical [14]. Some researchers have gone even further in an effort to reactivate or restore the tumor suppressor function of this P53 protein, this remains promising efforts despite the difficulties noted [15-20]. Despite the direct involvement of this mutation in the evolution of the disease, its research in LAL is not systematic; whatever the mechanism, the inactivation of the P53 protein is responsible for an adverse prognosis and resistance to chemotherapy; this has been proven in several studies [21-23]. As all human cancers, the mutation of the P53 gene in LALs preferentially affects the DNA binding site [24,25].

\section{Patients and Methods}

This exploratory prospective study of 41 patients with ALL, recruited consecutively from those attending the Center anticancer Emir abdel Kader of Oran from September 2014 to March 2017. They were patients with acute lymphoblastic leukemia aged 11 months to 14 years and a half with an average of 6.41 years \pm 42 months (24 are female and 17 male with a sex ratio $\mathrm{H} / \mathrm{F}$ equal to 0.70 ).

Diagnosis of ALL was based on bone marrow blast levels $\geq 20$ blasts; negative Sudan B black and immunophenotyping in favor of the lymphoid lineage. All patients followed the therapeutic protocols of the
European Organization for Research and Treatment of Cancer group EORTC58881.

According to the FAB 1976 classification (Frensh-AmericanBritish): $73.2 \%$ of patients have LAL2, $19.5 \%$ have LAL1 and $7.3 \%$ have LAL3. According to the European Group for Immunological Classification of Leukemias (EGIL) classification, $88 \%$ of patients are type B and $12 \%$ are type T. According to the time of research of the anomaly of P53 in the evolution of the disease; it is found that $19.5 \%$ of the patients $(8 / 41)$ were in the diagnosis phase; $65.9 \%$ (27/41) were in the remission phase and $14.6 \%(6 / 41)$ were in the relapse phase.

In our diagnostic strategy, the immunocytochemical (ICC) technique was chosen as a functional screening technique for P53 alterations $[10,26,27]$, whether deletions, mutations, 02 at the same time or other P53 abnormalities; The search for the P53 mutation in the samples with a positive ICC result was made by NGS (Next Generation Sequencing) (exon 04 to exon 09).

\section{Analysis of P53 Expression by Immunocytochemistry}

The antibody used in our study is anti-human Dako P53 clone 3186-11 (rabbit antibodies) and the visualization was done by the Dako EnVisionTM Flex system which is a revealing system (kit) consisting of: Dako EnVisionTM Flex/HRP: consists of a dextran chain on which a large number of peroxidase molecule (HRP: horseradish peroxidase) and secondary antibody molecule have been coupled. Dako EnVisionTM Flex DAB+Chromogen: consists of a concentrated solution of diaminobenzidine and a buffer containing hydrogen

*Corresponding author: Amine Moueden, Department of Hemobiology, University Hospital, Oran, Algeria, Tel: 00213552075649; E-mail: a.moueden@gmail.com

Received May 15, 2018; Accepted June 15, 2018; Published June 25, 2018

Citation: Moueden A, Benlaldj D, Boumeddane A, Seghier F (2018) Aberrant Expression of the p53 Tumor Suppressor Gene in Pediatric Acute Lymphoblastic Leukemia. J Blood Lymph 8: 216. doi:10.4172/2165-7831.1000216

Copyright: (c) 2018 Moueden A, et al. This is an open-access article distributed under the terms of the Creative Commons Attribution License, which permits unrestricted use, distribution, and reproduction in any medium, provided the original author and source are credited. 
peroxide. Dako EnVisionTM Flex Hematoxylin: for counterstaining. Rinse the slides with the wash buffer. Delimit an appropriate area on the smear by the Dako-Pen. Add $100 \mu \mathrm{L}$ of the peroxidase blocking solution for 5 minutes, then rinse with the Wash buffer. Add $100 \mu \mathrm{L}$ of diluted primary antibody $(0.644 \mathrm{mg} / \mathrm{L})$ for 20 minutes, then rinse with Wash buffer.

- Add $100 \mu \mathrm{L}$ of the conjugate (anti-P53 antibody coupled to an enzyme) for 20 minutes, then rinse with Wash buffer.

- $\quad$ Rinse with the Wash buffer for 05 minutes.

- Add $200 \mu \mathrm{L}$ of substrate for 10 minutes, then rinse with Wash buffer.

- Add $100 \mu \mathrm{L}$ of hematoxylin for 05 minutes for counterstaining.

- Rinse with distilled water after rinsing with Wash Buffer and then rinse again with distilled water.

Dehydrate by passing the smears in baths containing ethanol $70 \%$, 95\%, pure ethanol 02 times and xylene for 1 minute for each bath, the slides should be well mixed in the baths. Positive and negative controls should be tested at the same time as patient samples.

- A positive control (positive P53).

- 2 negative controls:

In the first negative control, lymphocytes from a normal subject are used and in the second negative control the negative control reagent (rabbit antibody not directed against human TP53) or the omission of the addition of anti-human antibodies is used. P53 or the addition of a normal serum).

\section{Reading}

There are 500 mononuclear cells; it is preferably by 02 observers.

The reaction is considered positive if at least $10 \%$ of the lymphoid cells show intense staining of the nucleus with the anti-P53 antibody: Positive reaction (Figure 1); Negative reaction (Figure 2).

\section{Statistical Analysis}

- The data was entered and analyzed on a computer support using the IBM SPSS statistics 21 software.

- A threshold of $0.05 \%$ is considered significant for all the statistical tests performed.

- The qualitative variables are expressed as a percentage or

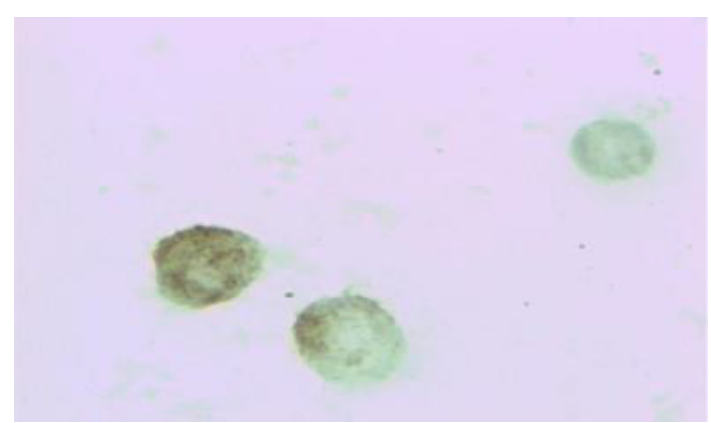

Figure 1: Positive reaction (seen at Magnification * 2200 by a Leica microscope coupled to a camera, left highly positive lymphoblast +++ , middle ++ , right slightly positive + ).

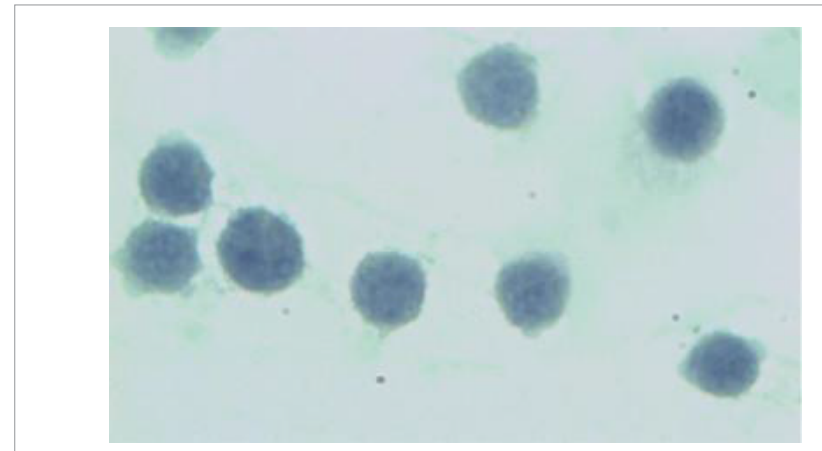

Figure 2: Negative reaction (seen at Magnification * 2200 by a Leica microscope coupled to a camera, blast cells do not take the brown color).

number of cases $\mathrm{n}$ on the total $\mathrm{N}$; and the quantitative variables are expressed as mean \pm standard deviation.

- The comparison of the qualitative variables was made by:

- The Chi-square test if the sample size is greater than 30 , applying Yates' correction when one of the contingency table counts is less than 5 . Otherwise it is done by the Fisher's exact test if the sample size is less than 30 .

- The comparison of 02 quantitative variables was made by:

- The Student $\mathrm{T}$ test when the sample distribution is normal. Otherwise, it is done by the Mann and Whitney test (U-test).

- The survival function is estimated using the Kaplan-Meier method.

- The comparison between the survival curves in the presence and in the absence of the P53 expression was made essentially by the logrank test.

- The construction of the multivariate model was carried out according to the model of Cox regression.

\section{Results}

In our study, we found that 05 cases out of 41 have percentage cells with positive immunocytochemical result greater than $10 \%$ of the lymphoid cells.

The different results of immunocytochemical reading are summarized in Table 1

The 41 patients are subdivided into 02 groups:

Group 1: composed of 5 patients presenting a positive ICC P53 result.

Group 2: composed of 36 patients with a negative ICC P53 result.

Thus the 02 groups of patients are in a second time compared with:

- Epidemiological data.

- Biological data

- Clinical and therapeutic data

- Bivariate and multivariate survival.

\section{Discussion}

\section{Epidemiological data}

In our study, the frequency of P53 abnormalities manifested 


\begin{tabular}{|c|c|c|c|c|}
\hline & Patient & Observer 1 & Observer 2 & Average \\
\hline Percentage & 01 & 24 & 19 & 21.50 \\
\hline Cells & 02 & 68.3 & 61.7 & 65.00 \\
\hline P53 ICC & 03 & 63.17 & 60.83 & 62.00 \\
\hline Positives & 04 & 28 & 22 & 25.00 \\
\cline { 2 - 5 } & 05 & 26.5 & 28.5 & 27.50 \\
\hline
\end{tabular}

Table 1: Results of the reading of the immunocytochemical technique of the 2 observers.

by hyperexpression of the P53 protein and detected by immunocytochemical technique is $12.2 \%$ ( 05 cases out of 41 ); whatever the research technique used the comparison of this frequency with that of several studies [22,27-32].

In fact, the frequency of P53 abnormalities is closely related to the time of finding this abnormality, as our study shows $(\mathrm{p}=0.011)$ where $60 \%$ of positive cases were found at the time of relapse, $20 \%$ at the time of the diagnosis and $20 \%$ at the time of remission $(p<0.011)$. And out of 08 patients who presented at the time of diagnosis, only 1 patient had a positive ICC P53 result (12.5\%), which shows that this abnormality is rare. at the time of diagnosis. Other studies have found a much lower frequency at the beginning of the disease, ranging between 2 to $3 \%$ [12]. This could be explained by the decreased number of patients at the time of diagnosis; in our cohort (08 patients). On the other hand, abnormalities of P53 are very frequent in the relapse phase reaching in our study 50\%. Although until 2001, the significance of P53 alterations in childhood ALL remained controversial because of small cohorts (not exceeding 51 patients) and non-standardization of treatment protocols $[28,33]$. In the 2011 study by Hof, et al., the follow-up from start to finish of 23 children with ALL revealed that $54 \%$ of P53 alterations occurred at the time of relapse [34].

According to the authors, it is unlikely that an increase in P53 expression before the initiation of therapy results from a mutation in the P53 gene, justifying this hypothesis by the fact that in their studies; P53 mutations in children's LALs occur in less than 5\% at the time of diagnosis and in 16 to $28 \%$ in the recurrence phase [35,36]. This could explain the case of our patient recruited at the time of diagnosis who presents a positive ICC $\mathrm{P} 53$ reaction without any mutation detected by sequencing or a $17 \mathrm{p}$ deletion detected by FISH.

In our study, sequencing in 03 P53 ICC positive cases did not reveal any $\mathrm{P} 53$ gene mutations. Thus, the FISH technique performed on the 03 cases presenting a positive ICC P53 reaction with no mutation at sequencing, did not find a 17p deletion; therefore, 03 P53 ICC positive cases show no P53 mutation or $17 \mathrm{p}$ deletion.

In the LALs, nuclear hyper expression of the P53 protein revealed by a positive ICC reaction without any P53 mutation or apparent $17 \mathrm{p}$ deletion could correspond to mechanisms of P53 stabilization [25,32,35-42].

The alterations of the P53 protein by ICC do not seem to be influenced by the age and the sex of the child $(p>0.05)$. To our knowledge, all the studies consulted on P53 in childhood ALL did not find any relation between these 02 parameters and the anomaly of P53 [43-45], however, its incidence increases with age especially. After 60 years, which could be the cause of the poor prognosis of adult ALL [24,46-48].

Our study did not find a significant statistical relationship between the presence of a P53 anomaly and the FAB classification $p>0.05$. This can be explained by the very high frequency of LAL 2 cases in our cohort (73.20\%). Thus, our study corresponds to that of Tsai et al. which finds no correlation between the FAB classification and the presence of an anomaly of P53 [48].

Some studies have found a very high frequency of the P53 mutation in Burkitt type like $[49,50]$ that of Preudhomme et al. which focused on only patients with LAL3 (Burkitt) newly diagnosed and found a frequency of $19 \%$ [42]; Stengel et al. study of 36 Burkitt-type ALL cases found a frequency of $58.3 \%$ [24].

Regarding the EGIL classification, in our study we found that the presence of an abnormality of P53 does not statistically depend on the immunophenotypic type of leukemia $\mathrm{p}>0.05$.

The rarity of the P53 mutation in LALTs was also found in the study by Jonveaux et al., performed on 30 patients with LALT where no patient presented the P53 mutation [50]. According to our study, Hecker et al. also found that the presence of the P53 mutation does not depend on the $\mathrm{B}$ or $\mathrm{T}$ phenotype [43]; on the other hand, other studies such as that of Addeo et al. found that the presence of the P53 mutation depends but little significantly on the EGIL classification $p=0.0470$ [27].

\section{Biological data}

In our study, we do not find a significant relationship between P53 abnormalities translated by hyperexpression of P53 and white blood cell count (Table 2), this is consistent with the study by Klobusicka et al. [44]. The peripheral blast level is not also influenced by the presence of an abnormality of P53 ( $\mathrm{p}=0.29$ ), this corresponds to the study by Hecker et al. which finds no correlation between the initial rate blasts and the presence of the P53 mutation [44].

\section{Clinical and therapeutic data}

In our study, there is no significant relationship between the results of the expression of P53 and the presence of a tumor lysis syndrome ( $p>0.05$ ), which results from the destruction of the tumor mass. To our knowledge; no study talks about the relationship between the presence of the P53 mutation and the lysis syndrome; although the latter is also considered to be a factor of poor prognosis.

In contrast, our study found a significant relationship between P53 abnormalities and the early response to prednisone $d 08(p=0.043)$, indicating the role of P53 in the regulation of corticosteroid-induced apoptosis in lymphocytes [35].

\section{Survival analysis}

In univariate analysis, we found that the presence of an abnormality of P53 in ALL is associated with event-free survival and shorter overall survival; with event-free survival averages (P53 V abnormality without P53 abnormality: $29.60 \pm 6.05$ months V $44.45 \pm 1.45$ months), and mean overall survival (P53 V anomaly without P53 abnormality: 39.06 \pm 3.98 months $\mathrm{V} 45.03 \pm 0.96$ ); this effect is well known in several recent studies [24,48]. Hof et al. study of an extended cohort of 265 children with ALL in the first relapse phase found a very strong link between P53 mutations and/or 17p deletions with event-free survival and overall survival $=0.001$ and $\mathrm{p}=0.002$ respectively [12].

In our work we found that the impact of the P53 anomaly on the event-free survival seems more significant than on the overall survival with respectively $p=0.001$ and $p=0.033$; this is in agreement with the study of Addeo et al. with respectively $p=0.003$ and $p=0.035$ [27]. In multivariate analysis, the results of our work show that the P53 anomaly is the only independent pejorative predictor of rapid evolution of eventfree survival $\mathrm{p}=0.047$ (Table 3); on the other hand, it is not in overall survival (Table 4 ). The study by Hof et al. found that the P53 anomaly 
Citation: Moueden A, Benlaldj D, Boumeddane A, Seghier F (2018) Aberrant Expression of the p53 Tumor Suppressor Gene in Pediatric Acute Lymphoblastic Leukemia. J Blood Lymph 8: 216. doi:10.4172/2165-7831.1000216

Page 4 of 6

\begin{tabular}{|c|c|c|c|}
\hline Biological data & $\begin{array}{c}\text { P53 ICC (-) } \\
(\mathrm{N}=36)\end{array}$ & $\begin{array}{c}\text { P53 ICC (+) } \\
(\mathrm{N}=5)\end{array}$ & Valeur $\mathbf{p}$ \\
\hline HB g/dl & $11 \pm 7.28$ & $09 \pm 6.08$ & $\begin{array}{c}0.26 \\
\times \\
\text { (NS) }\end{array}$ \\
\hline $\mathrm{WBC} / \mathrm{mm}^{3}$ at diagnosis & $27039.89 \pm 28512$ & $134720 \pm 202328$ & $\begin{array}{l}0.33 \\
\times \\
(N S)\end{array}$ \\
\hline Platelet $/ \mathrm{mm}^{3}$ at diagnosis & $264000 \pm 74666$ & $128800 \pm 178159$ & $\begin{array}{c}0.55 \\
\times \\
\text { (NS) }\end{array}$ \\
\hline Blasts \% in peripheral blood at diagnosis & $39.14 \pm 35.99$ & $59.60 \pm 34.50$ & $\begin{array}{c}0.29 \\
\times \\
(N S)\end{array}$ \\
\hline Blasts \% in bone marrow at diagnosis & $84.69 \pm 14.79$ & $94.40 \pm 2.51$ & $\begin{array}{c}0.12 \\
\times \\
\text { (NS) }\end{array}$ \\
\hline
\end{tabular}

ICC: Immunocytochemical Result; HB: Hemoglobin; WBC: Counts in Peripheral Blood

Table 2: Comparaison of Biological data between P53 ICC (-) and P53 ICC (+).

\begin{tabular}{|c|c|c|c|c|}
\hline & \multirow{2}{*}{$\begin{array}{c}\text { Hasard } \\
\text { Ratio }\end{array}$} & \multirow[t]{2}{*}{$\mathbf{p}$} & \multicolumn{2}{|c|}{ 95,0\% Confidential Interval Hasard Ratio } \\
\hline & & & Inférieure & Supérieure \\
\hline \multicolumn{5}{|l|}{ Gender } \\
\hline Male & 1 & & & \\
\hline Female & 0.937 & 0.944 & 0.155 & 5.680 \\
\hline \multicolumn{5}{|l|}{ Age } \\
\hline$<6$ years & 1 & & & \\
\hline$\geq 6$ years & 1.872 & 0.544 & 0.247 & 14.163 \\
\hline \multicolumn{5}{|l|}{ WBC/mm3 at diagnosis } \\
\hline$<10000 / \mathrm{mm}^{3}$ & 1 & & & \\
\hline$\geq 10000 / \mathrm{mm}^{3}$ & 3.876 & 0.302 & 0.296 & 50.844 \\
\hline \multicolumn{5}{|l|}{ Lysis syndrome } \\
\hline Oui & 1 & & & \\
\hline Non & 0.642 & 0.742 & 0.046 & \\
\hline \multicolumn{5}{|l|}{ Prednisone Response } \\
\hline Oui & 1 & & & \\
\hline Non & 0.435 & 0.475 & 0.044 & 4.261 \\
\hline \multicolumn{5}{|l|}{ P 53} \\
\hline ICC Négative & 1 & & & \\
\hline ICC Positive & 7.540 & 0.047 & 1.026 & 55.422 \\
\hline
\end{tabular}

Table 3: Multivariate analysis of event-free survival.

\begin{tabular}{|c|c|c|c|c|}
\hline & \multirow{2}{*}{$\begin{array}{c}\text { Hasard } \\
\text { Ratio }\end{array}$} & \multirow[t]{2}{*}{$\mathbf{P}$} & \multicolumn{2}{|c|}{$95,0 \%$ Confidential Interval Hasard Ratio } \\
\hline & & & Inférieure & Supérieure \\
\hline \multicolumn{5}{|l|}{ Gender } \\
\hline Male & 1 & & & \\
\hline Female & 1.63 & 0.582 & 0.286 & 9.288 \\
\hline \multicolumn{5}{|l|}{ Age } \\
\hline$<6$ years & 1 & & & \\
\hline$\geq 6$ years & 1.816 & 0.571 & 0.231 & 14.27 \\
\hline \multicolumn{5}{|l|}{$\mathrm{WBC} / \mathrm{mm}^{3}$ at diagnosis } \\
\hline$<10000 / \mathrm{mm}^{3}$ & 1 & & & \\
\hline$\geq 10000 / \mathrm{mm}^{3}$ & 11.75 & 0.149 & 0.414 & 333.26 \\
\hline \multicolumn{5}{|l|}{ Prednisone Response } \\
\hline Oui & 1 & & & \\
\hline Non & 1.39 & 0.775 & 0.141 & 13.83 \\
\hline \multicolumn{5}{|l|}{ P53 } \\
\hline ICC Négative & 1 & & & \\
\hline ICC Positive & 8.93 & 0.065 & 0.875 & 91.28 \\
\hline
\end{tabular}

Table 4: Multivariate analysis of overall survival. 
and the time of the first relapse are the two independent, rapidly evolving pejorative factors with $\mathrm{p}=0.001$ and $\mathrm{p}<0.001$ respectively [12]; in contrast to the Addeo et al. study where the P53 anomaly was not an independent predictor in event-free survival and overall survival [27].

\section{Conclusion}

The search for P53 gene abnormalities direct (mutations and deletions) or indirect (abnormalities of regulatory genes, abnormalities of effectors) should be established and is part of the pre-therapeutic assessment of all patients with LAL, avoiding ineffective and toxic therapeutic protocols thus improving life expectancy.

Our study also made it possible to illustrate the importance of the immunocytochemical technique as a functional technique in the screening of P53 abnormalities, whether it is a direct abnormality on the P53 gene (P53 gene mutation, 17p deletion) or an indirect abnormality on the complex. P53 (regulatory gene, effector molecules).

According to our study we suggest introducing the state of the P53 gene into the risk factors for acute lymphoblastic leukemia, thus we are interested to study the correlation of this anomaly with other risk factors like obesity, metabolic alterations and cardiovascular disease (CVD) [51].

\section{References}

1. Hainaut P (1999) Five Essential Questions about the Tumor Suppressor p53.

2. Kojima K (2014) (Role of p53 in leukemia). Rinsho Ketsueki 55: 1724-1730.

3. Leroy B, Anderson M, Soussi (2014) TP53 Mutations in Human Cancer: Database Reassessment and Prospects for the Next Decade. Hum Mutat 35 : $672-88$.

4. Nigro JM, Baker SJ, Preisinger AC, Jessup JM, Hostetter R, et al. (1989) Mutations in the p53 gene occur in diverse human tumour types. Nature 342: 705-708

5. Mills AA (2005) p53: link to the past, bridge to the future. Genes Dev 19: 2091 2099.

6. P. PCF. p53 and hematological malignancies. Pathology and Biology 1997; 45 : 777-908, 898-908

7. Yue X, Zhao Y, Xu Y, Zheng M, Feng Z, et al. (2017) Mutant p53 in Cancer: Accumulation, Gain-of-Function, and Therapy. J Mol Biol 429: 1595-1606.

8. Bouaoun L, Sonkin D, Ardin M, Hollstein M, Byrnes G, et al. (2016) TP53 Variations in Human Cancers: New Lessons from the IARC TP53 Database and Genomics Data. Hum Mutat 37: 865-876.

9. Moorman AV (2014) Does TP53 guard ALL genomes? Blood 124: 160-161.

10. Nagai J, Kigasawa H, Koga N, Katoh A, Nishihira H, et al. (1998) Clinical significance of detecting p53 protein in Burkitt lymphoma and B-cell acute lymphoblastic leukemia using immunocytochemistry. Leukemia \& Lymphoma 28: 591-597.

11. Miller DR, Miller LP (1990) Acute lymphoblastic leukemia in children: An update of clinical, biological, and therapeutic aspects. Crit Rev Oncol Hematol 10: 131164

12. Hof J, Krentz S, van Schewick C, Körner G, Shalapour S, et al. (2011) Mutations and Deletions of the TP53 Gene Predict Nonresponse to Treatment and Poor Outcome in First Relapse of Childhood Acute Lymphoblastic Leukemia. J Clin Oncol 29: 3185-3193.

13. Lin M, Liu Y, Jin J (1998) Study on MDM2 and p53 gene proteins expression on acute leukemic cells and its correlation with chemotherapeutic efficacy. Zhonghua xue ye xue za zhi=Zhonghua xueyexue Zazhi 19: 350-352.

14. Shindiapina P, Brown JR, Danilov AV (2014) A new hope: novel therapeutic approaches to treatment of chronic lymphocytic leukaemia with defects in TP53. Br J Haematol 167: 149-161.

15. Selivanova G (2014) Wild type p53 reactivation: From lab bench to clinic. FEBS Lett. 588: 2628-2638.
16. Velasco-Hernandez T, Vicente-Duenas C, Sanchez-Garcia I, Martin-Zanca D (2013) p53 restoration kills primitive leukemia cells in vivo and increases survival of leukemic mice. Cell Cycle 12: 122-132.

17. Li L, Wang L, Wang Z, Ho Y, McDonald T, et al. (2012) Activation of p53 by SIRT1 inhibition enhances elimination of CML leukemia stem cells in combination with imatinib. Cancer Cell 21: 140-142.

18. Hasegawa H, Yamada Y, Iha H, Tsukasaki K, Nagai K, et al. (2009) Activation of p53 by Nutlin-3a, an antagonist of MDM2, induces apoptosis and cellular senescence in adult T-cell leukemia cells. Leukemia 23: 2090-2101.

19. Cheng J, Yee JK, Yeargin J, Friedmann T, Haas M (1992) Suppression of acute lymphoblastic leukemia by the human wild-type p53 gene. Cancer Res 52: $222-226$

20. Simeonova (2007) Réactivation de p53 dans les tumeurs: une stratégie antitumorale prometteuse. Med Sci 23: 565-567.

21. Ahmed MB, Shehata HH, Moussa M, Ibrahim TM (2012) Prognostic significance of survivin and tumor necrosis factor-alpha in adult acute lymphoblastic leukemia. Clin Biochem 45: 112-116.

22. Hendy OM, Elghannam DM, El-Sharnouby JA, Goda EF, El-Ashry R, et al. (2009) Frequency and prognostic significance of murine double minute protein-2 overexpression and p53 genemutations in childhood acute lymphoblastic leukemia. Hematology (Amsterdam, Netherlands) 14: 335-340.

23. Diccianni MB, Yu J, Hsiao M, Mukherjee S, Shao LE (1994) Clinical Significance of p53 Mutations in Relapsed T-cell Acutev Lymphoblastic Leukemia. Blood Cancer J 84: 3105-3112.

24. Stengel A, Schnittger S, Weissmann S, Kuznia S, Kern W, et al. (2014) TP53 mutations occur in $15.7 \%$ of ALL and are associated with MYC-rearrangement low hypodiploidy, and a poor prognosis. Blood 124: 251-258.

25. Xu-Monette ZY, Medeiros LJ, Li Y, Orlowski RZ, Andreeff M, et al. (2012 Dysfunction of the TP53 tumor suppressor gene in lymphoid malignancies. Blood 119: 3668-3683.

26. Mattern J, Sauerbrey A, Volm M (1995) p53 protein detected by two different antibodies: relationship to proliferation and prognosis in acute lymphoblastic leukemia. Anticancer Res 15: 1043-1047.

27. Addeo R, Caraglia M, Baldi A, D'Angelo V, Casale F, et al. (2004) Prognostic role of bcl-xL and p53 in childhood acute lymphoblastic leukemia. Cancer Biol Ther 4: 39-45.

28. Felix CA, Nau MM, Takahashi T, Mitsudomi T, Chiba I, et al. (1992) Hereditary and acquired p53 gene mutations in childhood acute lymphoblastic leukemia. J Clin Invest 89: 640-647.

29. Agirre X, Novo FJ, Calasanz MJ, Larrayoz MJ, Lahortiga I, et al. (2003) TP53 is frequently altered by methylation, mutation, and/or deletion in acute lymphoblastic leukaemia. Mol Carcinog 38: 201-208.

30. Gustafsson B, Christenson B, Hjalmar V, Winiarski J (2000) Cellular expression of MDM2 and p53 in childhood leukemias with poor prognosis. Med Pediatr Oncol 34: 117-124

31. Wojcik I, Szybka M, Golanska E, Rieske P, Blonski JZ, et al. (2005) Abnormalities of the P53, MDM2, BCL2 and BAX genes in acute leukemias. Neoplasma 52: 318-324

32. Vilas-Zornoza A, Agirre X, Martín-Palanco V, Martín-Subero JI, San JoséEneriz E, et al. (2011) Frequent and Simultaneous Epigenetic Inactivation of TP53 Pathway Genes in Acute Lymphoblastic Leukemia. PloS One 6: e17012.

33. Gump J, McGavran L, Wei Q, Hunger SP (2001) Analysis of TP53 mutations in relapsed childhood acute lymphoblastic leukemia. J Pediat Hematol Onc 23 416-419.

34. Hof J, Krentz S, van Schewick C, Korner G, Shalapour S, et al. (2011) Mutations and deletions of the TP53 gene predict nonresponse to treatment and poor outcome in first relapse of childhood acute lymphoblastic leukemia. $J$ Clin Oncol 29: 3185-3193.

35. Ociepa T, Maloney E, Kamienska E, Wysocki M, Kurylak A, et al. (2010) Simultaneous assessment of p53 and MDM2 expression in leukemic cells in response to initial prednisone therapy in children with acute lymphoblastic leukemia. Pol J Pathol 61: 199-205.

36. Peller S, Rotter V (2003) TP53 in hematological cancer: Low incidence of mutations with significant clinical relevance. Hum Mutat 21: 277-284. 
Citation: Moueden A, Benlaldj D, Boumeddane A, Seghier F (2018) Aberrant Expression of the p53 Tumor Suppressor Gene in Pediatric Acute Lymphoblastic Leukemia. J Blood Lymph 8: 216. doi:10.4172/2165-7831.1000216

37. Insinga A, Monestiroli S, Ronzoni S, Carbone R, Pearson M, et al. (2004) Impairment of $\mathrm{p} 53$ acetylation, stability and function by an oncogenic transcription factor. The EMBO Journal 23: 1144-1154.

38. Nouman GS, Anderson JJ, Wood KM, Lunec J, Hall AG, et al. (2002) Loss of nuclear expression of the p33(ING1b) inhibitor of growth protein in childhood acute lymphoblastic leukaemia. J Clin Pathol 55: 596-601.

39. Lam V, McPherson JP, Salmena L, Lees J, Chu W, et al. (1999) p53 gene status and chemosensitivity of childhood acute lymphoblastic leukemia cells to adriamycin. Leukemia Research 23: 871-880.

40. Agirre X, Roman-Gomez J, Jimenez-Velasco A, Garate L, Montiel-Duarte C et al. (2013) ASPP1, a common activator of TP53, is inactivated by aberrant methylation of its promoter expression of apoptosis stimulating protein of $\mathrm{p} 53$ 2 (ASPP2) in human acute leukemia is associated with therapy failure. PLoS One 8: e80193.

41. Yamato K, Oka T, Hiroi M, Iwahara Y, Sugito S, et al. (1993) Aberrant expression of the p53 tumor suppressor gene in adult T-cell leukemia and HTLV-I-infected cells. Jpn J Cancer Res 84: 4-8.

42. Preudhomme C, Dervite I, Wattel E, Vanrumbeke M, Flactif M, et al. (1995) Clinical significance of p53 mutations in newly diagnosed Burkitt's lymphoma and acute lymphoblastic leukemia: a report of 48 cases. J Clin Oncol 13: 812-20.

43. Hecker S, Sauerbrey A, Volm M (1994) p53 expression and poor prognosis in childhood acute lymphoblastic leukemia. Anticancer Res 14: 2759-2761.

44. Mk Klobušická Jb (2001) Expression of p53 and Bcl-2 proteins in acute leukemias: an immunocytochemical study. Neoplasma 48.
45. Chiaretti S, Brugnoletti F, Tavolaro S, Bonina S, Paoloni F et al. (2013) TP53 mutations are frequent in adult acute lymphoblastic leukemia cases negative for recurrent fusion genes and correlate with poor response to induction therapy. Haematologica 98: e59-e61.

46. Chen J, Zhu B, Chen J, Li Y (2013) Genetic variations in MDM2 and P53 genes confer risk for adult acute lymphoblastic leukemia in a Chinese population. DNA Cell Biol 32: 414-419.

47. Salmoiraghi S, Montalvo MLG, Ubiali G, Tosi M, Peruta B, et al. (2016) Mutations of TP53 gene in adult acute lymphoblastic leukemia at diagnosis do not affect the achievement of hematologic response but correlate with early relapse and very poor survival. Haematologica 101: e245-e248.

48. Tsai T, Davalath S, Rankin C, Radich JP, Head D, et al. (1996) Tumo suppressor gene alteration in adult acute lymphoblastic leukemia (ALL). Analysis of retinoblastoma $(\mathrm{Rb})$ and p53 gene expression in lymphoblasts of patients with de novo, relapsed, or refractory ALL treated in Southwest Oncology Group studies. Leukemia 10: 1901-1910.

49. Farrell PJ, Allan GJ, Shanahan F, Vousden KH, Crook T (1991) p53 is frequently mutated in Burkitt's lymphoma cell lines. EMBO J 10: 2879-2887.

50. Jonveaux $P$, Berger $R$ (1991) Infrequent mutations in the P53 gene in primary human T-cell acute lymphoblastic leukemia. Leukemia 5: 839-840.

51. Giordano P, Muggeo P, Delvecchio M, Carbonara S, Romano A, et al. (2017) Endothelial dysfunction and cardiovascular risk factors in childhood acute lymphoblastic leukemia survivors. Int J Cardiol 228: 621-627. 